\section{Lembaran Sejarah}

\title{
Foreign Capital and Colonial Development in Indonesia: A Synthesis
}

\section{J. THOMAS LINDBLAD}

Leiden University, The Netherlands

\begin{abstract}
This article discusses impacts of investment by foreign firms, in particular Dutch firms, on economy and society in Indonesia during the late colonial period (19101940) and immediately after independence (the 1950s). It starts out with a survey of the historiography, arguing that impacts of foreign investment on the host country have not been sufficiently specified in the literature. It offers a digression on the dimensions of foreign investment in colonial Indonesia as inferred from newly available primary data highlighting the chief characteristics of such investment. The article surveys a variety of economic and social impacts on the macro level and the level of individual regions and selected firms, focusing in particular on impacts that have so far received scant attention. A major conclusion is that positive gains did materialize in the host country, both economic and social, but also that the gains stayed short of what could potentially have been realized. The Dutch private firms investing in colonial Indonesia did display a measure of corporate social responsibility but their initiatives and efforts in that vein could have reached, considering the profitability of their operations. If so, they would have had a significantly larger impact on economy and society in colonial Indonesia.
\end{abstract}

\begin{abstract}
Abstrak
Artikel ini membahas akibat dari investasi perusahaan asing, khususnya perusahaanperusahaan Belanda, terhadap ekonomi dan masyarakat di Indonesia pada masa kolonial akhir (1920-1940) dan setelah kemerdekaan (1950an). Artikel bermula dengan survei historiografi dan menunjukkan bahwa pengaruh investasi asing pada negara penerima kurang banyak mendapatkan perhatian dalam tulisantulisan akademis. Artikel ini menyajikan perubahan cara pandang akan investasi asing pada zaman kolonial dengan memanfaatkan data-data primer baru yang menekankan karakter-karakter utama investasi tersebut. Artikel ini mensurvei beragam pengaruh ekonomi dan sosial pada tingkat makro serta pada beragam daerah ataupun perusahaan, menekankan pada pengaruh yang selama ini sedikit mendapat perhatian. Kesimpulan besarnya adalah bahwa keuntungan positif didapatkan oleh negara penerima, baik secara ekonomis maupun secara sosial, tetapi juga bahawa keuntungan tersebut tetap jauh lebih sedikit daripada potensi yang bisa diperoleh. Perusahan swasta Belanda yang berinvestasi di Indonesia menunjukkan keinginan
\end{abstract}

Keywords: foreign investment; colonial Indonesia; business corporations

Kata kunci: investasi asing; Indonesia zaman kolonial; perusahaan 
melakukan investasi sosial (CSR) tetapi seringkali usaha mereka kurang dari yang diharapkan, mengingat tingkat keuntungan yang diperoleh dari usaha mereka. Jika mereka melakukan investasi sosial yang lebih besar, maka pengaruh mereka pada ekonomi dan masyarakat kolonial Indonesia akan lebih besar.

\section{Introduction}

Foreign investment formed an integral and inalienable part of the economy in colonial Indonesia. Students of colonialism are inevitably confronted with the important question of how economy and society in the colony were impacted by such investment. Who gained and who lost? Did overseas shareholders reap all, or most, of the benefits accruing from investment in the colony, or conversely, did the presence of foreign capital contribute in any substantial way to development in the colony at the time or after decolonization? Questions like these are not only important from an academic point of view. They have repercussions for current understanding of the legacy of colonial rule in a nation such as Indonesia, compelling us to pass judgment, in moral terms or otherwise, on our common past. This article offers a synthesis of recent findings about the impact of foreign private investment in Indonesia during the late colonial period and the years immediately after independence. ${ }^{1}$

Our focus is on investment of private capital for productive purposes. It does not include public investment by the colonial state or portfolio investment on stock exchanges. A favorable environment for foreign investment only materialized in the Indonesian archipelago after the colony had been opened up for private capital, from 1870 onwards. Yet, private foreign investment needed a gestation period of several decades before reaching an appreciable volume. This point was reached around 1910. The terms under which the Netherlands in 1949 at long last acquiesced in Indonesian independence included guarantees for continued operations by Dutch-owned business in Indonesia after the transfer of sovereignty. In this way, economic decolonization, as opposed to the political one, was delayed in Indonesia until the late 1950s when remaining Dutch enterprises were taken over and eventually nationalized (Lindblad, 2008: 177-208). Due to the delay in economic decolonization, as opposed to political decolonization, the existing colonial context of operations by foreign investors remained in

1) This article reports about a research program, entitled 'Foreign capital and colonial development in Indonesia', that was carried out at Leiden University in the Netherlands during the years 2012-2016. The program was financially supported by the Netherlands Organisation for Scientific Research (Nederlandse Organisatie voor Wetenschappelijk Onderzoek, NWO). Results include two forthcoming PhD dissertations by Frank Ochsendorf and Mark van de Water (see their contributions to this volume below) and a website, entitled www.colonialbusinessindonesia.nl. This article incorporates the discussions at two international conferences devoted to this research program, held at Leiden in December 2014 and in Yogyakarta in August 2016. 
place also after independence had been attained, albeit only for a brief period of time.

The article consists of four sections. A brief overview of the modern historiography of foreign investment in colonial Indonesia serves as the logical point of departure. It is followed by an impression of the dimensions of realized foreign investment. The impacts of such investment on the colonial economy are discussed in some detail. Impacts on colonial society, in particular the indigenous Indonesian society, are considered in the fourth and final substantive section.

\section{Modern Historiography}

Indonesian economic history has since the 1980s developed into a field of study in its own right. One consequence was a more critical appraisal of the role of foreign capital in the colonial economy, an assessment beyond an older and at times self-congratulatory literature, which stresses the great contributions made by foreign capital to Indonesia and its peoples (van Helsdingen 1941).

The reorientation in the scholarly literature was already apparent in collective works reporting from international conferences on Indonesian economic history held in the 1980s and early 1990s. The economist Angus Maddison argued that foreign direct investment had had a negative impact on economic development in Indonesia because of profits flowing out of the colony on an appreciable scale. Maddison coined the term 'double drain' referring to the tendency of both Western corporations and Chinese merchants to transmit profits abroad (Maddison, in: Maddison \& Prince [eds], 1989: 15-43). Other contributions discussed the emergence of a corporate network in colonial Indonesia and business strategies adopted by major Dutch investors (à Campo, 1995; Lindblad, in: Lindblad [ed.], 1996).

Indonesia is particularly well endowed with international textbooks on its economic history in colonial times. In her textbook, known by its subtitle 'A history of missed opportunities', Anne Booth shows how private investment increased rapidly in the 1910s and 1920s, far ahead of government investment. The ratio between total capital stock and gross domestic product (GDP) climbed from one-third in 1913 to four-fifths in 1930 (Booth, 1998: 255). The great importance of private foreign investment is similarly stressed in the multi-authored textbook focusing on the emergence of a national economy in Indonesia compiled by Howard Dick and others. The peak in 1930 is set at a staggering accumulated value of foreign-held assets at four billion guilders ( $\$ 1.6$ billion). The resulting corporate network contrasted a small number of large Dutch firms against a large number of smaller firms owned and managed by Dutch residents of the colony (Dick et al., 2002: 116).

The relationship between private capital investment and colonialism 
also receives attention in the more recent textbook on Indonesian economic history by Jan Luiten van Zanden and Daan Marks. Their calculations show that colonial Indonesia accounted for 40 per cent of total Dutch overseas investment, representing 22 per cent of wealth in the Netherlands and contributing 8 per cent of the mother-country's GDP (van Zanden \& Marks, 2012: 129). In her latest work, comparing Indonesia before and after independence, Anne Booth addresses the issue whether remittances of profits by investors in the colony were excessively large, whilst also touching on possible contributions by private foreign investment to the colony's economic development (Booth, 2016: 22).

In conclusion, the international historiography of Indonesian economic history does acknowledge the great significance of foreign private investment in the colonial context. Yet, in the literature it is still not spelt out what the precise impact of such investment was on economy and society. One ready explanation lies in the shortage of detailed statistical information. There are only a few global estimates of accumulated capital stock at scattered points in time. The sole running series with annual data is based on a backward extrapolation from indemnification claims submitted by private Dutch companies after nationalization in the late 1950s (Creutzberg, 1977). Apart from the speculative nature of such an exercise, there is reason to doubt whether the data accurately reflect the true value of seized properties.

A source with greater potential is a directory of business firms in colonial Indonesia that had been incorporated under Dutch law. This directory was published annually from the late 1880s to the end of effective Dutch colonial rule (Handboek, 1888-1940). We may readily assume that the directory includes all foreign-owned firms. Firms owned and managed by local residents of Chinese descent also often sought the legal status offered by incorporation under Dutch law; many of them are therefore also included. By contrast, indigenous Indonesian enterprises are scarcely ever listed as these enterprises generally operated under different legal conditions.

The directory cites equity as reported by each individual firm. Although requiring much time-consuming processing, this information enables us to estimate the accumulated volume of corporate capital stock in any given year whilst also offering insights into the composition of investment holdings. One pioneering effort covered only the early period when foreign private investment was still in its infancy (à Campo, in: Lindblad [ed.], 1996). By way of follow-up, another effort targeted the period of rapid expansion, but the analysis was virtually restricted to only one single year of observation, 1930 (Lindblad, 1998: 68-83). A full-fledged processing of this highly laborintensive source has since been undertaken for eight selected years at regular intervals during the period 1910-1940. ${ }^{2}$ Preliminary findings are incorporated

2) I gratefully acknowledge the contribution by my assistants at Leiden University, 
below. It needs to be pointed out here that equity as reported by investors offers a fuller representation of actual investment than incoming flows of capital in official balance of payments statistics. Much investment was realized by profits ploughed back into the company and does not figure at all in the statistics on balance of payments. As a source of information on private investment in colonial Indonesia, the directory of incorporated private firms appears superior to both balance of payments data and extrapolations from claims submitted decades later.

\section{Dimensions of Foreign Investment}

Any study of the impact of foreign investment on economy and society must start with the very dimensions of such investment. Foreign private investment was only undertaken on an appreciable scale in colonial Indonesia from the early twentieth century onwards. One examination of equity data for incorporated firms put accumulated paid-up capital stock at 1.7 billion guilders in 1913 (à Campo, in: Lindblad [ed.], 1996: 79). This figure virtually coincides with a contemporary estimate at US\$ 675 million for 1914 (Callis, 1942: 36). Subsequent processing of my own with respect to the following years rendered an estimate of accumulated equity at about 3.7 billion guilders in 1930 (Lindblad, 1998: 78). This figure resembles other, independent estimates for that year, citing an accumulated total of four billion guilders. According to one contemporary source, total capital stock was somewhat reduced during the economic depression of the 1930s, yet still amounted to US\$ 1.4 billion ( 3.5 billion guilders at the Gold Standard rate) by the late 1930s (Callis, 1942: 36). ${ }^{3}$ These older estimates can now be corroborated by the newest figures.

Total equity as reported by incorporated firms increased from 1.3 billion guilders in 1910 to 2.8 billion in 1920 and from there to 4.4 billion in 1930, eventually touching 4.9 billion in $1940 .{ }^{4}$ But how much of this enormous amount of accumulated equity was actually foreign-held? The directory of incorporated enterprises obviously does not identify firms by

Thomas de Greeve and Jelmer Puylaert, in constructing the database Colonial Business Indonesia (CBI). The data are stored in the Excel file 'CBI Database ID', accessible at www. colonialbusinessindonesia.nl.

3) Callis includes investment by Chinese residents of colonial Indonesia, which he estimates at 150 million guilders in 1930.

4) Calculations based on CBI, file 'CBI Database ID', accessible at www. colonialbusiness.nl. Equity was generally stated in Dutch guilders. If not, a conversion was done into Dutch guilders at the exchange rates prevailing at the time. An aggregation based on several thousand individual firms inevitably runs the risk of double counting whenever mother companies and subsidiaries are both listed. This could only be corrected for the conspicuous case of Royal Dutch (Koninklijke) with its subsidiary BPM (Bataafsche Petroleum Maatschappij, Batavian Petroleum Company), held jointly with British-owned Shell. Only the equity of the subsidiary firm is included in the calculations. 
nationality nor does it provide designations such as 'foreign' or 'domestic'. Nevertheless, the source does contain sufficient clues for a rough classification of firms by nationality or origin.

Designations of nationality were attached to the information from the database by application of a few simple criteria. ${ }^{5} \mathrm{~A}$ firm with headquarters overseas - in the Netherlands or third countries - was by definition a foreignowned enterprise; this also applies to firms using foreign currency when citing equity. Firms owned by indigenous Indonesians or local Chinese are recognized by the name of the firm or its owners. The former undeniably fall into the category 'domestic' investment, but the situation is more ambivalent for Chinese residents of colonial Indonesia. By Chinese law, these businessmen were citizens of China and merely subjects under Dutch colonial rule without enjoying Dutch citizenship. Yet, Chinese firms were fully entrenched in the local economy and not in any way conceived as 'alien' by the colonial authorities. For all intents and purposes, investment by local Chinese in colonial Indonesia was domestic investment. Foreign investment, therefore, equals total incorporated equity reduced by the equity of Chinese and indigenous Indonesian firms.

Within the large category of foreign-held assets, a further differentiation is needed for purposes of analysis. Non-Dutch foreign firms are identified from having headquarters in another country than the Netherlands or by using another currency than the Dutch guilder in citing equity. There were two types of Dutch private firms operating in the colony, those run from headquarters in the Netherlands and those with local headquarters. The former may arguably be perceived to be more 'foreign' than the latter (Lindblad, 1998: 72-73). However, it is too speculative to operationalize such a distinction in terms of a differential impact on host economy and society. From an Indonesian point of view, a Dutch firm remained 'foreign', whether or not it had its headquarters in the Netherlands or in the archipelago. In addition, there is no sensible way of separating Indo-European companies from firms at large using Dutch names or citing owners with Dutch personal names. The large category of firms labeled as 'Dutch' therefore embraces a wide range of different types of companies, with headquarters in colonial Indonesia or the Netherlands and with totok Europeans or Indo-Europeans at the helm. The category also includes a fair number of non-Dutch foreign firms opting for local headquarters under Dutch law, thus appearing more 'Dutch' than they actually were.

Our estimates of private foreign investment in colonial Indonesia in

5) The version of 'CBI Database ID' with nationality or origin assigned on a firm basis, labelled 'CBI Database Nation', is not yet accessible at the website www. colonialbusinessindonesia.nl. It is available upon request. 
selected years between 1910 and 1940 are given in Table $1 .^{6}$ The estimates are consistently higher than the figures cited in the literature (Callis, 1942: 36; Creutzberg, 1977; Lindblad, 1998: 78). Our new estimates are 20 per cent higher for 1914 or 1915, 5-14 per cent higher for 1930, and 9-36 per cent higher for the late 1930s or 1940. The order of magnitude remains the same with the same long-run trend, embracing rapid expansion during the 1910s and early 1920s, a slowdown of the expansion in the late 1920s and decline in the 1930s.

Table 1. Total equity of incorporated foreign firms in colonial Indonesia, 1910-1940.

\begin{tabular}{ccccc}
\hline & $\begin{array}{c}\text { Foreign-held equity } \\
\text { (million guilders) }\end{array}$ & $\begin{array}{c}\text { Dutch firms from the } \\
\text { Netherlands (\%) }\end{array}$ & $\begin{array}{c}\text { Dutch firms in colonial } \\
\text { Indonesia (\%) }\end{array}$ & $\begin{array}{c}\text { Other foreign } \\
\text { firms (\%) }\end{array}$ \\
\hline 1910 & 1200 & 70 & 25 & 5 \\
1915 & 2050 & 65 & 22 & 13 \\
1920 & 2705 & 65 & 24 & 11 \\
1925 & 3755 & 68 & 21 & 11 \\
1930 & 4220 & 72 & 18 & 10 \\
1935 & 4305 & 71 & 15 & 14 \\
1940 & 4775 adjusted 3820 & 66 & 13 & 21 \\
\hline
\end{tabular}

Source: See note 6.

The pace of accumulation was particularly fast in the first half of the 1910s due to the very low initial level; the figure for 1915 exceeded that of 1910 by 70 per cent. The increase over intervening five-year intervals amounted to 32 per cent in the second half of the 1910s and 39 per cent in the first half of the 1920s. The level in 1930 only exceeded that of 1925 by 12 per cent as a very large volume had already been accumulated by the mid-1920s. Change was negligible in the early 1930s but amounted to a drop of 11 per cent in the second half of the decade if the effect of the devaluation of Dutch currency is incorporated into the estimate.

The share of Dutch firms run from the Netherlands was exceptionally high corresponding to 68 per cent on average of total foreign investment throughout the period of observation. Although aggregated equity differs in absolute terms, the high relative proportions of unmistakably Dutch firms resemble the percentages in earlier estimates (Callis, 1942: 36; Lindblad, 1998: 77). The share of firms here designated as 'Dutch' on account of maintaining

6) Source to Table 1: CBI, file 'CBI Database ID', accessible at www. colonialbusinessindonesia.nl, as well as with designations of nationality added under the label 'CBI Database Nation'. See Mark van de Water, 'The development and character of foreign investment in late colonial Indonesia' below, Table 4. Aggregate equity values are given in nominal terms at current prices and expressed in Dutch guilders with a constant gold content until 1935. The estimate for 1940 was adjusted for the lower exchange rate of the Dutch currency following the devaluation of the guilder by 20 per cent vis-à-vis the pound sterling in September 1936. 
headquarters in the colony averaged 20 per cent over the period as a whole but declined significantly from 1930 onwards. This category comprised both Dutchmen setting up business locally and foreign investors of non-Dutch origin operating as if they were 'Dutch'. The true Dutch share in total foreignheld equity is likely to have been higher than 68 per cent but lower than 88 per cent.

Foreign investment of apparent non-Dutch origin was strongly dominated by British-owned firms, mostly managed from London offices. These firms accounted for 8-9 per cent on average from 1920 onwards. Other non-Dutch investors included Belgian, American and Japanese companies. ${ }^{7}$ The evidence suggests that some of these companies did not disclose full information about their equity holdings. More complete information on this score would add to the overall total while reducing the Dutch share.

The high Dutch share cannot be fully ascribed to overt colonial policy. From 1870 onwards, the Dutch colony was opened up for foreign investment from both the Netherlands and third countries. However, Dutch investors did possess a comparative advantage above rivals from other countries because of their familiarity with language, regulations and institutions. This was in turn reinforced by personal contacts and an increasingly powerful colonial lobby in the Netherlands (Taselaar, 1998). The disproportionately high share of the metropolitan mother-country in colonial investment was mirrored elsewhere in Southeast Asia, notably in British Malaya, where British firms ranked first and Dutch firms second (Lindblad, 1998: 14).

The remaining domestic segments of incorporated private business in the colony, about 5 per cent in terms of listed equity, consisted almost exclusively of Chinese business firms, whereas firms owned by indigenous Indonesians, mostly Javanese, represented a minute share of paid-up equity. Domestic total equity increased from only about 60 million guilders in 1910 to almost 260 million in 1925, then dropped to 135 million in 1935, yet climbed above 300 million in 1940. The small domestic sector of incorporated business was even more strongly affected by the worldwide economic depression of the1930s compared to the foreign firms.

Total foreign investment in colonial Indonesia was without doubt impressive. It can be compared with key macroeconomic variables such as GDP and total export revenue. However, we need to keep in mind that foreign investment is measured here as a stock concept, reflecting value accumulated over time, whereas GDP and export revenue are both expressed as flow concepts, referring to individual years. Only a rough comparison by order of magnitude is methodologically justified. It then transpires that total

7) Registered non-Dutch equity in 1935 and 1940 included major banks active in Asian markets, such as the Hongkong Shanghai Banking Corporation (HSBC), the Overseas Chinese Banking Corporation (OCBC) and the Bank of China. 
foreign-held equity corresponded to a proportion of estimated GDP rising from 57 per cent in 1915 to 62 per cent in 1925 and 69 per cent by 1930 (Booth, 1998: 255). ${ }^{8}$ Such statistics clearly reaffirm the enormous leverage by size alone of foreign investment in the economy of colonial Indonesia.

It can be similarly demonstrated that foreign investment represented an ever larger multiple of annual export earnings of the entire colonial economy. Accumulated foreign equity corresponded to more than twice as much as total export revenues in the 1910s and 1925, three times as much in 1930, nine times as much at the nadir of the depression in 1935 and four times as much in 1940 (Korthals Altes, 1987: 90-94). The sole outlier was the year 1920 when export revenues were bolstered by an extreme short-run inflation of prices, resulting in export revenues being almost on par with accumulated foreign equity.

The world of corporate business in colonial Indonesia was very extensive and elaborate, judging from its sheer physical dimensions. Already the early explorations of the Handboek as a source of historical information rendered a total of 2686 individual firms in 1913 (including Chinese) and 2116 foreign firms in 1930 (excluding Chinese) (à Campo, in: Lindblad [ed.], 1996: 74; Lindblad, 1998: 74). The results of present calculations are given in Table $2 .{ }^{9}$

Table 2. Number and average equity of foreign firms in colonial Indonesia, 1910-1940.

\begin{tabular}{ccccc}
\hline Foreign-owned firms & $\begin{array}{c}\text { Dutch firms from the } \\
\text { Netherlands (\%) }\end{array}$ & $\begin{array}{c}\text { Dutch firms in colonial } \\
\text { Indonesia (\%) }\end{array}$ & $\begin{array}{c}\text { Average equity } \\
\text { (thous. guilders) }\end{array}$ \\
\hline 1910 & 1677 & 32 & 64 & 705 \\
1915 & 2342 & 29 & 64 & 814 \\
1920 & 2822 & 25 & 69 & 910 \\
1925 & 2597 & 26 & 67 & 1381 \\
1930 & 2121 & 31 & 64 & 1904 \\
1935 & 1563 & 38 & 55 & 2555 \\
1940 & 1699 & 34 & 60 & 2322 \\
\hline
\end{tabular}

Source: See note 9.

The network of foreign-owned business expanded rapidly during the 1910s with ever more business firms being set up. The 1920s was a time of consolidation with falling numbers and an increasing average firm size. In

8) As a caveat to this comparison, it should be mentioned that the GDP estimates cited in the source might have been recalculated into constant prices, whereas our data on equity are in current prices.

9) Source to Table 2: CBI, CBI, file 'CBI Database ID', accessible at www. colonialbusinessindonesia.nl, as well as with designations of nationality added under the label 'CBI Database Nation'. See also Mark van de Water, 'The development and character of foreign investment in late colonial Indonesia' below, Tables 2 and 4. 
1930, there were 25 per cent fewer individual companies but they were on average twice as large. The tendency towards less but larger firms continued into the 1930s and only came to a halt at the end of the decade as the colonial economy began to recover from the depression. In all years except 1935, the share of Dutch companies with local headquarters among all foreign firms was at least twice as high as the share of Dutch companies run from the Netherlands. Yet, the latter commanded a far larger accumulated equity than the former. By implication, Dutch firms run from the Netherlands were on average significantly larger than those run from local headquarters in Indonesia. In 1930, for instance, the averages were 4.7 million guilders against scarcely more than half a million. ${ }^{10}$

Foreign investment remained important in newly independent Indonesia under Soekarno, although little fresh investment entered the country with the oil industry forming the sole exception to the rule. There are scarcely any statistics at all on total investment apart from claims for compensation submitted by hundreds of Dutch companies that were seized and nationalized in the late 1950s. The 564 firms (out of 739) for which statistics are available claimed a total loss of 2.7 billion guilders (Creutzberg, 1977: 33-4). This figure was considered a gross exaggeration by the Indonesian authorities, arguing that replacement of depreciated assets had been lagging behind ever since the Japanese occupation and the Indonesian Revolution. In September 1966, at long last, agreement was reached between the Netherlands and Indonesia about the amount of compensation to be paid. The grand total was set at 689 million guilders, including accumulated interest. Payments were made by the Indonesian government in annual installments between 1973 and 2003 (Lindblad, 2008: 208).

After sketching the historiography and the global dimensions of foreign investment in colonial Indonesia, the time is ripe for a discussion of impacts on economy and society in the colonial period and immediately after independence.

\section{The Economic Impact}

In seeking to identify impacts on the economy, it is instructive to differentiate by level of analysis. At the highest or most abstract level of analysis, we focus on the economy as a whole. Here we are primarily concerned with the relationship between foreign investment and key macroeconomic variables such as GDP, export revenue and employment. At the lowest level of analysis, the individual business firm, we turn to indirect or even unintended effects

10) The share of Chinese firms in the total number of incorporated companies rose from one-fifth in the 1910s to one-quarter in the 1920s but dropped somewhat in the 1930s. The Chinese firms were far smaller than foreign companies. Average equity increased from less than 200,000 guilders in 1920 to 300,000 in 1930 and further to slightly above 700,000 by 1940 . 
such as industrial and fiscal linkages, construction of infrastructure and skills development among the local population. At an intermediate level, we target individual regions with their statistical idiosyncrasies and collective experience of private enterprises. Not all variables and effects can be studied in the same depth at each level of analysis.

Actual impact needs to be reviewed against the background of conditions under which such impact could materialize in the first place. The scope of impact was determined by both business strategies in the individual enterprise and colonial economic policy vis-à-vis foreign capital. The most decisive determinant was the profitability of foreign investment and the extent to which profits were transmitted overseas. The argument runs as follows. The more profits transmitted overseas, the less scope for a substantial impact on the local economy, and vice versa.

Earlier studies of foreign investment at the highest level of analysis made use of the backward extrapolations of indemnification claims of the Dutch firms mentioned above. Despite its limitations as a source of accurate information, this series has the unique quality of providing annual data that can be statistically linked to macroeconomic variables. A regression analysis with total export revenue produces a statistically significant coefficient of correlation $\left(\mathrm{R}^{2}=0.66\right)$ (Lindblad, in: van Zanden [ed.], 1996: 115). There was clearly is a strong link between foreign investment and exports. The high profitability of producing for the world market attracted foreign capital, whereas more investment enhanced the capacity of export production. The two reinforced each other.

Estimates inferred from equity as reported in the directory of corporate business are not available on an annual basis. In addition, the estimates express accumulated stock, not annual flows as is the case with export revenues, or other macroeconomic variables for that matter. The only methodologically warranted option is to compare relative changes over time, an approach that is not compatible with rigorous time series analysis. This is done here with respect to total exports and national income or GDP. Contemporary estimates of national income do exist for the 1920s and 1930s (Creutzberg, 1979), but those figures have since been superseded by far better reconstructions. A comparison of relative change over five-year intervals shows long-run trends for foreign investment, GDP and total exports (Table 3). ${ }^{11}$

Up to 1925 , the relative change over a five-year interval was considerably larger in accumulated foreign investment than in GDP levels, up but GDP rose faster than foreign investment during the second half of the 1920s. In the 1930s, the two moved in opposite direction, first with foreign

11) Sources to Table 3: CBI, file 'CBI Database ID' at www.colonialbusinessindonesia. nl; van der Eng, in: Maddison, Rao \& Shepherd (eds), 2002: 171-2; Korthals Altes, 1987: 90-4. 
investment virtually stagnant and GDP even declining, then with investment declining and GDP recovering. The causal link between foreign investment and GDP appears to have been from the late 1920s.

Table 3. Relative changes in foreign investment, GDP and export revenue, 1910-1940.

\begin{tabular}{cccc}
\hline & Foreign investment (\%) & Gross Domestic Product (\%) & Total export revenue (\%) \\
\hline $1910 / 15$ & +70.3 & +14.5 & +87 \\
$1915 / 20$ & +32.1 & +10.3 & +158 \\
$1920 / 25$ & +38.7 & +13.5 & -16 \\
$1925 / 30$ & +12.4 & +22.4 & -35 \\
$1930 / 35$ & +2.0 & 5.5 & 0 \\
$1935 / 40$ & -13.8 & +30.0 & +63 \\
\hline
\end{tabular}

Sources: See note 11.

Patterns of change were even more incongruous with respect to export earnings. A relative change of about the same dimensions can only be spotted for the expansionary phase in the early 1910s and the depression years in the first half of the 1930s. The extreme inflation of export prices in 1920 severely impairs comparison with the preceding five-year period. For the 1920s and the second half of the 1930s, relative changes over five-year intervals point in opposite directions. The lack of fit can only be ascribed to the incompatibility of accumulated foreign investment as a stock concept and annual export revenue as a flow concept.

Dutch colonialism bequeathed a highly traditional economic structure to Indonesia characterized by heavy reliance on production of primary commodities for exports. Such an economic structure implies a strong dependence on world markets. The external impetus from foreign markets for products from colonial Indonesia was highly favorable during the 1910s and 1920s but turned into its opposite during the worldwide economic depression in the 1930s. Indonesia's extreme vulnerability to changes in world markets was reinforced by export-oriented foreign investment. This constituted a lasting impact on economic development in Indonesia at large.

No analysis along similar lines can be undertaken with respect to another vital macroeconomic variable, employment. To the extent there was a registration of the labor force in the colony in the first place, employees were not differentiated by the nationality of employers. The only possibility, which is far from easy, is to use existing knowledge about the monopolization of certain branches of industry by foreign capital. A few examples suffice to illustrate this approach. The 180 odd sugar factories in Java in the late 1930s each employed several hundred workers, there were several hundred tobacco and rubber estates in Java and Sumatra, employing hundreds of workers each, the tin mines of Bangka and Billiton and the oil refineries in Sumatra and 
Kalimantan all counted several thousand coolies. In this manner, it should be possible to at least arrive at a rough indication of the order of magnitude of employment generated by foreign capital in the colonial economy.

Employment is not only important in terms of numbers of workers in foreign-owned enterprises, but also because of paid-out wages. Such payments were brought into circulation in the indigenous economy. Considering the very size of the foreign-owned sector of the economy, total paid-out wages must have been substantial. But rates remained low, even during the boom of the 1920s (van Zanden \& Marks, 2012: 115-6). This above all reflects the far greater leverage of foreign employers above domestic workers in the colonial economy.

Industrial census data do not differentiate by nationality of owners or origin of capital nor do they offer clues as to which domestic industries may have emerged due to the presence of foreign capital. The same applies to tax revenues that could possibly represent fiscal linkages arising from operations by foreign firms. Profits at Dutch-owned firms with headquarters in the Netherlands were subject to taxation in the mother-country, not in the colony. Data on investment in infrastructure and education refer to public expenditures, not to outlays of foreign firms. Such impacts cannot be effectively studied at the highest level of analysis.

The intermediate level of analysis, the individual region, provides limited possibilities for finding indicators of an economic impact. There are regional statistics on foreign trade, but not on total income, let alone regional employment. North Sumatra and Southeast Kalimantan were known as leading recipients of foreign investment. In 1930, these two regions alone accounted for one-half of all export revenue earned by the Outer Islands of colonial Indonesia (Clemens, Lindblad \& Touwen, 1992: 53-59).

The best evidence on economic impacts at the intermediate level of individual regions refers to linkages between operations by foreign firms and the surrounding local economy. Linkages come in sorts. Industrial linkages may be either backward, in the form of auxiliary operations providing inputs for the foreign enterprise, or forward, using output of the foreign firm as inputs into further processing. Multiplier effects due to income generated by the activities of the foreign firm include fiscal linkages due to increasing tax revenues as well as final demand or consumption linkages, reflecting increased local spending, including a rising demand for foreign imports.

Using North Sumatra as a case study, it has been demonstrated that such linkages did indeed materialize on an appreciable scale, in particular during the 1920s and 1930s (Ochsendorf, 2015). Backward linkages proved to be of greater importance than forward ones in terms of industrial processing. Both fiscal and final demand linkages were of a considerable magnitude in the region, as testified by the very substantial share of wages in total 
operational costs of tobacco and rubber estates. In passing, it is noted that trading opportunities arising from final demand linkages were often seized by immigrant population groups, such as local residents of Chinese, Indian or Banjarese descent.

The micro level of analysis, drawing on evidence about individual firms, is arguably suitable for exploring further linkages. What kinds of auxiliary economic activities nearby emanated from the operations of the foreign firm? What were the ramifications in terms of local spending, considering that the very size of the labor force may compensate for the low average wage rate? How much did the colonial authorities receive as tax payments, funds that could potentially be applied to improve infrastructure and other facilities in the area? Selected case studies of foreign enterprises may shed light on such issues, using information from private business archives that were so far not consulted for such a purpose.

Three case studies in particular have the potential of offering new insights into linkages generated by foreign investment in the colonial setting. The three are the Deli Company (Deli Maatschappij) in tobacco cultivation in North Sumatra, HVA (Handels Vereeniging 'Amsterdam', 'Amsterdam' Trading Association') in export agriculture (mainly sugar in Java and rubber in Sumatra), and the Billiton Company (Billiton Maatschappij) in tin mining on the island of Belitung. All three dated from the nineteenth century: Billiton from 1860, Deli from 1870, HVA from 1878. They were all sizeable enterprises with paid-up equity eventually ranging from 21 million guilders (Billiton), 60 million (HVA) and 65 million (Deli Company). They were large employers. Billiton counted 10,000 coolies already in the 1910s, the Deli Company had 24,000 coolies on the payroll in the booming 1920s, whereas HVA reportedly employed as many as 170,000 workers at the concern's 36 estates, many of whom engaged on a temporary basis during the harvest season. Financial results were generally satisfactory, enabling generous dividend payments to shareholders overseas, including in the case of Billiton the Dutch state. Tax payments by Billiton and the Deli Company in particular were impressive, whereas HVA was inclined to reinvest profits at its estates (Lindblad, Ochsendorf \& van de Water, 2013; van de Water, 2015). Such evidence suggests a considerable scope for fiscal and final demand linkages generated by the activities of these three Dutch firms with a prominent position in the world of corporate business in colonial Indonesia.

Our analysis needs to be extended to incorporate also the potential scope for an economic impact. Evidence on firm strategies to encourage auxiliary economic activities nearby may be spotted in business archives, although such initiatives would be rated as charity and not commensurate with the main priority of the firm which was to make profit for the shareholders. The entire period from 1870 up to the advent of protectionism in 1933 was marked by 
liberal economic policies. Interference with operations by foreign enterprises was limited to surveillance by the Labor Inspectorate, set up for the Outer Islands in 1908, with the intention of preventing abuse in the system of coolie labor outside Java. Otherwise, the foreign firms were by and large left in peace. The scope for economic impacts was therefore primarily determined by the profitability of invested foreign capital.

The idea of a colonial drain dates back to the public discourse in the second half of the 1940s, in the shadow of Dutch military intervention against the newly established Indonesian Republic. Together with an associate, later Nobel Prize laureate Jan Tinbergen calculated how much the Netherlands stood to lose if the colony were to gain independence, arguing that much of Dutch national income accruing from the colonial possession consisted of profits made by Dutch firms in Indonesia (Derksen \& Tinbergen, 1945). Such flows of profits into the Netherlands would most likely be significantly reduced at a transfer of sovereignty to the Republic of Indonesia.

The analysis of the Dutch economists was confined to the impact of Indonesian independence for Dutch the economy, leaving out all possible repercussions for the economy of newly independent Indonesia. Among Indonesian nationalist leaders, there was an underlying apprehension of the presence of foreign capital in colonial society, yet no Indonesian economists ventured on an attempt to calculate what would be the consequences of radically changed conditions for foreign investors, in particular private firms from the one-time metropolitan mother-country. One of the very few who explicitly envisaged a profound transformation of the economy, Soejono Hadinoto, sufficed to speak in rather general terms about the conversion of a 'colonial economy' into a 'national economy' (Hadinoto, 1949). In the event, private Dutch firms continued to operate in Indonesia under conditions akin to those of colonialism for another eight years after the transfer of sovereignty in 1949.

The concept of drainage was for the first time applied to the colonial economy in Indonesia in a $\mathrm{PhD}$ dissertation in the late 1940s (Berkhuysen, 1948). The colonial drain could arguably be held responsible for the fact that Indonesia was such a poor country at independence, despite having experienced a considerable economic expansion during the decades preceding the Japanese occupation and the Indonesian Revolution. The concept of colonial drain came to figure prominently in the recent, revitalized discussion about Indonesia's colonial past (Maddison, in Maddison \& Prince [eds], 1989; Booth, 2007: 107-111; 2016: 33-34).

The key to understanding the colonial drain is profitability in private foreign-owned firms. The issue is not whether profits were made or not. To make profits was the very rationale of investing capital in the colony in the first place. The issue is whether profits were extraordinary or excessive, 
beyond what could be considered a justifiable remuneration for the access to capital, technology and management provided by the foreign investor. A proper measurement of profits suffers from a lack of data except when firms are studied on an individual basis using business archives, which is obviously not feasible for a substantial number of companies. The most readily available proxy for profits is the rate of dividends paid out annually to shareholders, judged against the standard return of six per cent on invested capital.

Various calculations of profitability, using dividend rates as a proxy for profit rates, have been presented for different sectors or branches of industry, both in the past and more recently. In 1993, Pierre van der Eng disputed the very existence of a colonial drain, seeking to demonstrate that profits made by Dutch firms in colonial Indonesia were not excessive but formed a reasonable compensation to the owners of capital (van der Eng, 1993). His argument was heavily criticized in the international literature (Gordon, 2010).

Paid-out dividends are specified in the directory of corporate business for a fair number of individual companies. Regrettably, the source does not distinguish between a zero dividend and a want of information on dividend payment. Preliminary calculations suggested averages that were conspicuously high for the 1910s and 1920s, but predictably lower in the 1930s (Lindblad, 2014, 2015). Meanwhile, the international discourse on colonial profits has resulted in a consensus that historical dividend rates can only serve as a proxy for rates of gain if offset against developments in share prices (Buelens \& Frankema, 2016). As a consequence, more realistic average rates can here only be calculated for firms fulfilling the twin requirement of citing dividends in the corporate directory and being listed on the Amsterdam Stock Exchange. Results do indeed indicate lower gains on investment of capital than as suggested by nominal dividend rates. ${ }^{12}$ Foreign investors in colonial Indonesia in fact realized two types of gain that were not fully comparable to each another, one expressed by the dividend rate, the other representing by an increase in the value of shares. Average dividend rates adjusted for share price development do not justify the conclusion that foreign investment in colonial Indonesia generated profits that can be labeled disproportionate or excessive in comparison to prevailing 'normal' rates of return on investment.

Negative impacts of foreign investment in colonial Indonesia are readily identified, for instance with respect to land use as local residents were deprived of the best soils, access to irrigation, notably in the Java sugar industry. Negative side effects may also include the exploitation of labor through payment of pitifully low wages, not to speak of outright abuse of employees as reported from estates in North Sumatra in the very early twentieth century. The adverse effects of the presence of foreign capital in

12) For detailed results see my 'The profitability of Dutch business in late colonial Indonesia' below. 
the colony have been discussed at length elsewhere and need not be reiterated here. The focus in the preceding section has been on economic impacts that have so far attracted less attention in the literature. We now turn to the impact on colonial society, in particular indigenous Indonesian society.

\section{The Social Impact}

The presence of foreign capital without doubt had important ramifications for colonial society at large, but these impacts are more difficult than those pertaining to the economy. Variables used to depict society at large do not readily lend themselves for juxtaposition with volumes of foreign investment. There is, to cite just one obvious example, no sensible way of linking accelerated population growth in colonial Indonesia at the time with rising foreign investment, except by an all too general argument that foreign investment brought economic expansion which in turn may have stimulated population growth. Still, foreign investment did generate an increase in tax revenue even if much profit was not taxed at all or taxed elsewhere (van Zanden \& Marks, 2012: 127-128).

The volume of the colonial budget, largely based on tax revenue, increased from less than 150 million guilders to more than 1 billion guilders during the peak inflationary years 1920 and 1921, only to fall back to a range of 700-900 million guilders in the mid- and late 1920s. The spectacular increase and subsequent decline reflected the fate of the Ethical Policy of the colonial state (van Zanden \& Marks, 2012: 99).

The Ethical Policy had been launched in 1901, gaining momentum in particular from about 1910. Yet, this took place before foreign investment reached a significant volume. In addition, the Ethical Policy was motivated by the stark contrast between widespread poverty among the indigenous population and the large profits which in the past had been pocketed by the Dutch state, not by Dutch private investors. The policy's inception and implementation stood apart from investment by private Dutch firms. Although not officially abandoned, the Ethical Policy effectively came to a conclusion in the mid-1920s, which coincided with the peak in foreign investment at a time of economic expansion and increasing profits (Dick et al., 2002: 117-121). This surely does not suggest a systematic relationship.

The increase in public expenditure over the 1910s and 1920s was impressive also in a comparative perspective. Expressed in per capita terms, government revenues in colonial Indonesia were at the time roughly on par with the level in the Philippines, Thailand and Burma, and even higher than in French Indochina, but far behind British Malaya (Booth, 2007: 73). The enlarged scope for expenditures by the colonial administration was in particular used for public investment in infrastructure. In addition, there was at least a potential considerable scope for expenditure on public facilities 
benefitting the population at large such as healthcare and education. A systematic analysis confronting tax revenues from foreign firms with public outlays on social facilities has yet to be undertaken for colonial Indonesia.

From a comparison across colonial powers in Southeast and East Asia, Anne Booth concludes that the record of the Dutch was particularly poor in terms of educational achievements. Levels of literacy were alarmingly low and only a tiny proportion of indigenous people received any education at all beyond elementary school (Booth, 1998: 272; 2007: 138). As a consequence, supervisory and management functions in private business were virtually inaccessible for the overwhelming majority of the population. This was reinforced by the colonial policy of restricting opportunities for people of non-European descent to learn Dutch. Proficiency in Dutch was absolutely essential in order to obtain any higher position in private business or public service. The least that can be said on this account is that foreign firms contributed to a perpetuation of this state of affairs to the extent that they did not erect facilities for training. Education did not count among the priorities of private companies doing business in colonial Indonesia.

The regional level of analysis seems to offer more fertile grounds for spotting evidence of social impacts. Case studies from West Java and Southeast Kalimantan show that indigenous entrepreneurship was sometimes fostered or stimulated by the activities of foreign firms. A system of mutual co-operation developed between foreign and local producers of tea in West Java, whereas in Southeast Kalimantan indigenous rubber soon overtook estate rubber in importance. In both cases, the presence of foreign capital in the region instilled a new mentality and new behavior with obvious benefits to local indigenous society (Ochsendorf, 2016).

After independence, Indonesia was confronted with an acute shortage of skills, which may justifiably be ascribed to policies pursued under the aegis of colonial rule. As part of the agreement on the transfer of sovereignty from Dutch authority to the Indonesian Republic in 1949, Dutch private firms intent on continuing operations in Indonesia pledged to make an effort to train Indonesians, especially indigenous Indonesians, for higher positions in the companies. The subsequent process of so-called Indonesianisasi in the 1950s gave rise to much disappointment. It all went too fast to the taste of the Dutch firms and too slow for the Indonesian authorities (Lindblad, 2008: 161-171). A regional case study may offer additional insights. Despite pressure by the Indonesian authorities, progress in training indigenous employees remained embarrassingly slow in the plantation belt of North Sumatra (Ochsendorf \& van de Water, 2014).

The best place to look for evidence of actual impacts is at the lowest level of analysis, that of the individual business firm. Two of the case studies mentioned above, the Deli Company and the Billiton tin mine, offer 
interesting detailed information. The Deli Company set up estate schools for local children and founded a separate auxiliary company for the supply of clean water in Medan and its environs. The company also took the initiative to construct a railway network in the region, delegated to a separate subsidiary, the Deli Railway Company (Deli Spoorweg Maatschappij). The railways obviously served the estates in North Sumatra but increasingly also benefitted the local population. At the Billiton tin mining corporation, social impacts included facilities for vocational training, a medical clinic, a small-scale foundation for welfare services in general and road construction (Ochsendorf \& van de Water, 2014). ${ }^{13}$

Improvements of the physical infrastructure seem to have benefitted adjacent local society the most. One example is the Serajoedal Steam Tram Company (Serajoedal Stoomtram Maatschappij) in the region of Banyumas in Central Java. The tramways were constructed in order to provide convenient transport from the region's sugar factories to the ports on Java's north coast. Again, such facilities represented an unintended positive side-effect for the local population (Ochsendorf, 2016). But the individual foreign firm does not constitute the very lowest level of analysis. We must not overlook how the presence of foreign capital contributed to shaping the minds of the colonized people. Such social impacts may also have had political repercussions, notably among representatives of the Indonesian nationalist movement. This is a topic which so far has received little attention in both the Indonesian and the international literature. Suffice it to say here that operations by foreign firms were likely to instill a distrust of market capitalism among the Indonesian people. This in turn may explain the attractiveness of the ideals of social democracy, as opposed to outright socialism or communism, felt by leading figures in the nationalist movement, men who more often than not ascended to key government posts after independence.

Again, there was clearly a negative side to the way in which the operations of foreign firms affected colonial society, although such effects might have been less tangible than in the case of economic impacts. Largescale mobilization of labor by foreign firms is likely to have had a disruptive influence on both village communities and the lives of many thousands of individual laborers recruited in Java to work as coolies in the Outer Islands. The intention of the research presented here has not been to further pursue these lines of exploration but rather to give attention to social impacts that have received less attention in the literature.

\section{Conclusion}

A brief survey of the relevant modern historiography tells us that the pivotal

13) See further Frank Ochsendorf, 'Colonial corporate social responsibility: Company healthcare in Java, East Sumatra and Belitung, 1910-1940’ below. 
role of foreign capital in the economic and social development of colonial Indonesia is generally acknowledged in the literature, yet without specifically indicating what the impacts on economy and society were. The aim of our endeavor was therefore to identify such impacts. This was done against the background of a sketch of the sheer dimensions of foreign investment in colonial Indonesia. Five key characteristics of such investment stand out: a sustained expansion over time, a strong Dutch predominance, a link with exports, an extensive corporate network, and a continuous consolidation of business units. All of these features were important in determining the impact of operations by foreign firms in the colonial setting, at the time and possibly also after independence.

In our search for impacts, we distinguish between three levels of analysis: the macro level of the entire economy or society, the individual region and the individual business firm. The macro level was applicable to a limited extent with regard to economic impacts, scarcely at all for social impacts. The regional perspective proved especially useful for economic impacts, whereas case studies of individual business firms offered insights into both economic and social impacts.

The balance sheet for economic impacts looks as follows. Foreign investment contributed positively to GDP, export revenues and employment, and final demand in the surrounding economy was bolstered by substantial payments of wages, despite persistently low wage rates. Industrial linkages did materialize but only to a limited extent. On the negative side of the balance sheet, we find, amongst others, the perpetuation of the traditional economic structure with its accompanying extreme dependence on world markets for primary products. Even if profit rates were not necessarily excessively high, the large-scale transfer of financial returns to shareholders overseas did represent a very substantial drain on the resources of the colonial economy. The conclusion appears inescapable that actual positive economic impacts were far less substantial than what could potentially have been the case. Only part of the potential for gain for the colonial economy was utilized.

The balance sheet for social impacts similarly lists positive effects, notably in the development of indigenous entrepreneurship and improvements of infrastructure. Some schooling and welfare services were provided, albeit on a modest scale. Such evidence testifies to a certain measure of corporate social responsibility among the private Dutch firms in colonial Indonesia. The foremost negative social impact as discussed here refers to the perpetuation of ethnic segregation in colonial society, which effectively curtailed opportunities for an upward social mobility by indigenous Indonesians. It is disputable what the political impact was of foreign investment in the late colonial period. After independence, the conspicuous retained presence of Dutch capital fuelled economic nationalism, culminating in the takeover and 
nationalization of virtually all Dutch enterprises still in Indonesia in the years 1957-1959. Just as with the economic impacts, it appears that a great deal more could have been done with the available resources than what actually occurred. Again, only part of the potential was utilized.

\section{Bibliography}

Berkhuysen, A.P.H. 'De drainage theorie voor Indonesië', $\mathrm{PhD}$ thesis, Leiden University, 1948.

Booth, Anne. The Indonesian economy in the nineteenth and twentieth centuries: A history of missed opportunities. London: Macmillan, 1998.

Booth, Anne. Colonial legacies: Economic and social development in East and Southeast Asia. Honolul: University of Hawai'i Press, 2007.

Booth, Anne. Economic change in modern Indonesia: Colonial and post-colonial comparisons. Cambridge: Cambridge University Press, 2016.

Buelens, Frans and Ewout Frankema. 'Colonial adventures in tropical agriculture: New estimates of returns to investment in the Netherlands Indies, 1919-1938', Cliometrica, Vol. 10 No. 2, 2016, pp. 197-224.

Callis, H.G. Foreign capital in Southeast Asia. New York: Institute of Pacific Relations, 1942.

Campo, J.N.F.M. à. 'Strength, survival and success; A statistical profile of corporate enterprise in colonial Indonesia 1893-1913', Jahrbuch für Wirtschaftsgeschichte, Vol. 46, 1995, pp. 45-74.

Campo, J.N.F.M. à. 'The rise of corporate enterprise in colonial Indonesia, 18931913', in: J. Thomas Lindblad (ed.), Historical foundations of a national economy in Indonesia, 1880s-1990s. Amsterdam: North-Holland, 1996, pp. 71-94.

Clemens, Adrian, J. Thomas Lindblad \& Jeroen Touwen. Changing Economy in Indonesia. Vol. 12B. Regional patterns in foreign trade 1911-1940. Amsterdam: Royal Tropical Institute, 1992.

Creutzberg, P. Changing Economy in Indonesia. Vol. 3. Expenditure on fixed assets. Amsterdam: Royal Tropical Institute, 1977.

Creutzberg, P. Changing Economy in Indonesia. Vol. 5. National income. Amsterdam: Royal Tropical Institute, 1979.

Derksen, J.B.D. \& J. Tinbergen. 'Berekeningen over de economische betekenis van Nederlandsch-Indië voor Nederland', Maandschrift van het Centraal Bureau voor de Statistiek, Vol. 40, 1945, pp. 210-216.

Dick, Howard et al. [= Howard Dick, Vincent J.H. Houben, J. Thomas Lindblad \& Thee Kian Wie]. The emergence of a national economy in Indonesia: An economic history of Indonesia, 1800-2000. Crows Nest, NSW: Allen \& Unwin, 2002.

Eng, Pierre van der. 'The "colonial drain” from Indonesia, 1823-1993'. Research paper. Canberra: Australian National University, 1993.

Eng, Pierre van der. 'Indonesia's growth performance in the twentieth century', in: Angus Maddison, D.S. Prasada Rao \& William F. Shepherd (eds), The Asian economies in the twentieth century. Cheltenham: Elgar, 2002, pp. 143-179.

Gordon, Alec. 'Netherlands East Indies: The large colonial surplus of Indonesia, 1878-1939', Journal of Contemporary Asia, Vol. 40 No. 3, 2010, pp. 425-443.

Hadinoto, Soejono. Ekonomi Indonesia: Dari ekonomi kolonial ke ekonomi nasional. Jakarta: Jajasan Pembangunan, 1949. 
Handboek voor cultuur-en handelsondernemingen in Nederlandsch-Indië. Amsterdam: De Bussy, 1888-1940.

Helsdingen, W.H. van. Daar werd wat groots verricht. Amsterdam: Elsevier, 1941.

Korthals Altes, W.L. Changing Economy in Indonesia. Vol. 7. Balance of payments 18221939. Amsterdam: Royal Tropical Institute, 1987.

Lindblad, J. Thomas. 'Business strategies in late colonial Indonesia', in: J. Thomas Lindblad (ed.), Historical foundations of a national economy in Indonesia, 1890s-1990s. Amsterdam: North-Holland, 1996, pp. 207-228.

Lindblad, J. Thomas. 'The economic relationship between the Netherlands and colonial Indonesia, 1870-1940', in: J.L. van Zanden (ed.), The economic development of the Netherlands since 1870. Cheltenham/Brookfield: Elgar, 1996, pp. 109-119.

Lindblad, J. Thomas. Foreign investment in Southeast Asia in the twentieth century. London: Macmillan, 1998.

Lindblad, J. Thomas. Bridges to new business: The economic decolonization of Indonesia. Leiden: KITLV Press, 2008.

Lindblad, J. Thomas. 'Booming business in colonial Indonesia: Corporate strategy and profitability during the 1920s'. Paper presented at the 23rd conference of the International Association of Historians of Asia, Alor Star, Malaysia, August 2014 [www.colonialbusinessindonesia.nl] .

Lindblad, J. Thomas, Frank Ochsendorf \& Mark van de Water. 'Foreign investment and Dutch colonialism: Case studies from Indonesia'. Paper presented at the 7th Euroseas conference in Lisbon, Portugal, July 2013 [www. colonialbusinessindonesia.nl].

Maddison, Angus. 'Dutch income in and from Indonesia, 1700-1938', in: Angus Maddison \& Gé Prince (eds) (1989) Economic growth in Indonesia, 1820-1940. Dordrecht and Cinnaminson, NJ: Foris, 1989, pp. 15-42 [also published in: Modern Asian Studies Vol. 23, pp. 645-670].

Ochsendorf, Frank. 'Gains from foreign investment for indigenous society in North Sumatra, 1860-1960'. Paper presented at the World Economic History Congress, Kyoto, Japan, August 2015 [www.colonialbusinessindonesia.nl].

Ochsendorf, Frank. 'Foreign capital and indigenous economic development in Indonesia: Spillovers and linkages in a colonial setting'. Paper presented at the international workshop on 'Colonial Business in Indonesia: The impact of foreign investment on economy and society', Yogyakarta, August 2016 [www.colonialbusinessindonesia.nl].

Ochsendorf, Frank \& Mark van de Water. 'Changing circumstances and strategies: A new era of business in newly independent Indonesia'. Paper presented at the 23rd conference of the International Association of Historians of Asia, Alor Star, Malaysia, August 2014 [www.colonialbusinessindonesia.nl].

Taselaar, Arjen. De Nederlandse koloniale lobby: Ondernemers en de Indische politiek 19141940. Leiden: CNWS, 1998.

Water, Mark van de. 'Dutch investment in the late colonial period and after Indonesian independence: Three case studies'. Paper presented at the World Economic History Congress in Kyoto, Japan, August 2015 [www. colonialbusinessindonesia.nl].

Zanden, Jan Luiten van \& Daan Marks. An economic history of Indonesia, 1800-2010. London: Routledge, 2012. 
Vol. 14 No. 1 April 2018

\section{Website}

Colonial Business Indonesia (CBI), at www.colonialbusinessindonesia.nl . 